\title{
Laboratory Evaluation of Undrained Shear Strength of a Soft Fine Grained Soils
}

\author{
Suleiman Khatrush**, Ghassan El-Gehani** \\ * Civil Engineering Department, Faculty of Engineering and Architecture, Istanbul Gelisim University, Istanbul, Turkey \\ **Department of Civil Engineering, Faculty of Engineering, University of Benghazi, Benghazi, Libya \\ (sasmohamed@gelisim.edu.tr, ghasa34@gmail.com)
}

*Corresponding Author; Suleiman Khatrush, Civil Engineering Department, Faculty of Engineering and Architecture, Istanbul Gelisim University, Tel: +90 212422 7000, Fax: +90 212422 7401, sasmohamed @ gelisim.edu.tr

\begin{abstract}
The determination of undrained shear strength of soils is commonly achieved using triaxial testing in which specimen is carefully prepared before testing to maintain its original field condition. However, for soft soils preparing and handling specimens without causing any disturbance is a difficult job and may not always be successful. Other laboratory testing techniques can be adopted provided they can produce reliable results for such cases and can overcome the problem of pretest preparation process and hence avoiding any alteration of sample field condition. Extensive laboratory investigation on a soft marine soil recovered from sea bed offshore of Benghazi city, the testing program involves investigation of the basic geotechnical properties, focusing specifically on the determination of the undrained shear strength of such soils as determined by both the conventional unconsolidated undrained triaxial testing (UU) and the simple laboratory vane shear testing device (Miniature shear vane MV). The resulting shear strength obtained by UU-triaxial test, and resulting shear strength measured by Miniature shear vane MV were examined, compared and discussed on the light of other research works. Furthermore, the problems faced during testing soft samples in triaxial apparatus was also presented. The resulting undrained shear strength obtained by UU-triaxial test was found generally lower than that produced by Miniature shear vane MV which is attributed to sample disturbance before testing in triaxial. The study also demonstrates that despite of high scatter, the undrained shear strength obtained by MV can be reasonably comparable with the results of other investigations on soft soils.
\end{abstract}

Keywords: Soft soils; Undrained strength; Index properties; Laboratory testing.

\section{Introduction}

Soft soils usually a source for many problems to geotechnical engineers, because of their low shear strength and liability to exhibit large deformation. The correct evaluation of shear strength is very important for achieving safe design and avoiding the incidence of instability.

Measurement of undrained shear strength in the laboratory is commonly made using triaxial testing on a cylindrical specimen directly recovered from the field after they have been subjected to certain sample preparation to fit with test apparatus. Triaxial test is relatively expensive and time consuming, furthermore soft soils are susceptible to certain degree of disturbance during sampling, handling and other pretest process [1,2].

The adoption of simple testing devices may be a possible alternative for evaluating undrained shear strength of soft soils, with respect to cost, time and problems of sample disturbance is extremely demanded.

Many researchers utilized strength index devices for measuring the undrained shear strength for cohesive soils; Nearing [3] used Miniature vane, pocket penetrometer and fall cone devices as indicators for the effect of prestress on shear strength of clay, Leoni [4] adopted the Torvane and pocket penetrometer, for measuring shear strength of reconstituted soils, Vahdifard et al [5] used pocket pentrometer, pocket 


\section{Khatrush and El-Gehani, Vol.7, No.3, 2021}

geotester and pocket vane shear for evaluating the strength changes of stabilized high water content soils, Howard and Badran [6] carried out a comparison study of hand held devices (Torvane and penetrometer) with the unconfined compression test for low strength cementitious material. The laboratory vane shear test was also adopted for measuring shear strength of remolded soil [7,8,9]. Velosa, et al [10] carried out an investigation on soft marine deposits using vane shear test and UU triaxial test on undisturbed samples. $\mathrm{Li}$, et al [11] used different laboratory tests including Torvane, Miniature vane and UU traixial tests on calcareous marine clays. Ebrahimian et al [12] published results of geotechnical charactrization using laboratory tests including UU triaxial, Pocket penetrometer, Torevane and Miniature vane on recovered undisturbed samples from deep marine deposits.

The main objective of the present investigation is to demonstrate and discuss the potential of UU-triaxial testing to reasonably evaluate the undrained shear strength of soft marine soils, and to examine the capability of the simple strength index device such as the Miniature vane shear to comparably estimate the undrained shear strength of soft soils.

\section{Soil samples}

A total of 125 cores of marine soil recovered from shallow depths ( 0 to 6.0 meter) from sea bed of Benghazi offshore were available for conducting the laboratory investigation. The laboratory work consists of tests of soft marine soils, mainly for the evaluation of undrained shear strength by means of unconsolidated undrained triaxial test (UU) and the Miniature vane shear (MV).

Cores which reserved in $76 \mathrm{~mm}$ plastic tubes were cut to the required lengths either to be ready for extracting smaller samples for triaxial testing or to directly conduct the strength index testing without extraction from the reserved tube. Implementing the vane shear device MV is rapid and easy, it is not involving additional process of sample preparation as in triaxial test, hence avoiding extra disturbance. The test is directly made while sample remains inside sampling tube. For smaller size samples required for triaxial testing, extraction of $35 \mathrm{~mm}$ specimens were made according to the method described in ASTM - D3213 [13]. However, for such soft soils this method was not always successful since about $50 \%$ of the prepared samples were exhibited high degree of disturbance and became insufficient for strength testing therefore they have been discarded from testing in the triaxial. Testing of soft soil is not an easy task, and therefore it requires extra care and special precautions in order to minimize sample disturbance. Samples extracted from tubes are prepared into suitable sizes so that the height to diameter ratio is equal or greater than two. Samples are handled very carefully in order to avoid distorting their original shape. Some samples especially those having high natural water content and which showed extra softening and hence, require extra care against bulging under its own weight are provided with some kind of support before placing it inside the rubber membrane and rapidly placed in the triaxial cell to minimize disturbance.

\section{Basic soil properties}

Soil classification tests including grain size analysis, Atterberg limits, physical properties such as water content, specific gravity, and bulk density and were determined for all samples from all depths. Other properties such as carbonate content was also obtained. The range of index and other basic properties are presented in Table 1. The void ratio of each sample was calculated by considering the samples are fully saturated and using the measured values of specific gravity and water content for the specified sample.

Table 1. Summary of the basic soil properties

\begin{tabular}{|lr|c|c|c|}
\hline \multicolumn{2}{|c|}{ Property } & Minimum & Maximum & Mean \\
\hline Liquid limit & LL \% & 30.9 & 90.3 & 38.7 \\
\hline Plastic limit & PL \% & 20.6 & 57.0 & 26.7 \\
\hline Plasticity index $\quad$ PI \% & 10.3 & 33.3 & 12.0 \\
\hline Water content $\quad$ Wc \% & 30.0 & 80.1 & 48.9 \\
\hline Specific gravity GS & 2.4 & 2.8 & 2.6 \\
\hline Bulk density $\gamma_{\mathrm{b} \quad(\mathrm{Mg} / \mathrm{m} 3)}$ & 1.6 & 2.3 & 1.9 \\
\hline Void ratio $\quad \mathrm{F}$ & 0.8 & 2.7 & 1.3 \\
\hline Fine fraction & Fr \% & 25.9 & 98.5 & 82.9 \\
\hline Carbonate content CO3 \% & 29 & 93.5 & 59.5 \\
\hline
\end{tabular}

The results are shown plotted in the soil plasticity chart in Fig. 1, the majority of the points are located below A-line, and according to Unified Soil Classification System (USCS), the soil is mostly classified as low plasticity silt (ML) or clay (CL) although some samples are of high plasticity $(\mathrm{CH}, \mathrm{MH})$, they were excluded from the testing program. The soil is containing large amount of fine material of an average of $83 \%$.the majority are of silt fraction. The average value of liquid limit is $39 \%$ and only few samples show relatively high liquid limit, the plasticity index in most cases is not having a wide range.

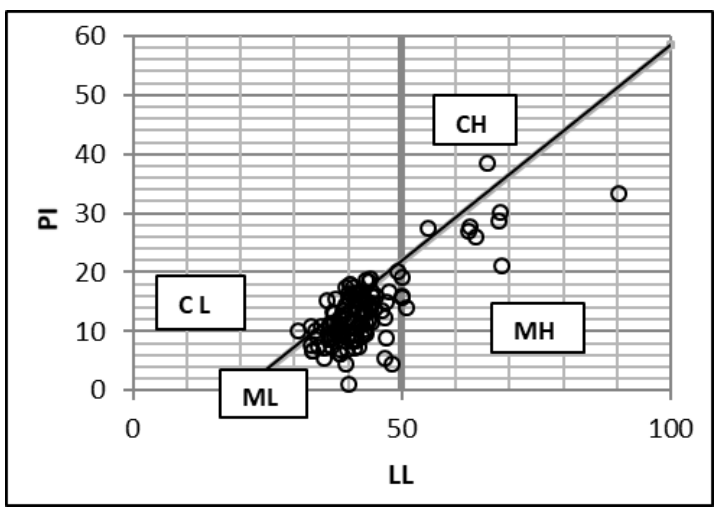

Fig. 1. Distribution of soil plasticity results within the Plasticity chart 
Khatrush and El-Gehani, Vol.7, No.3, 2021

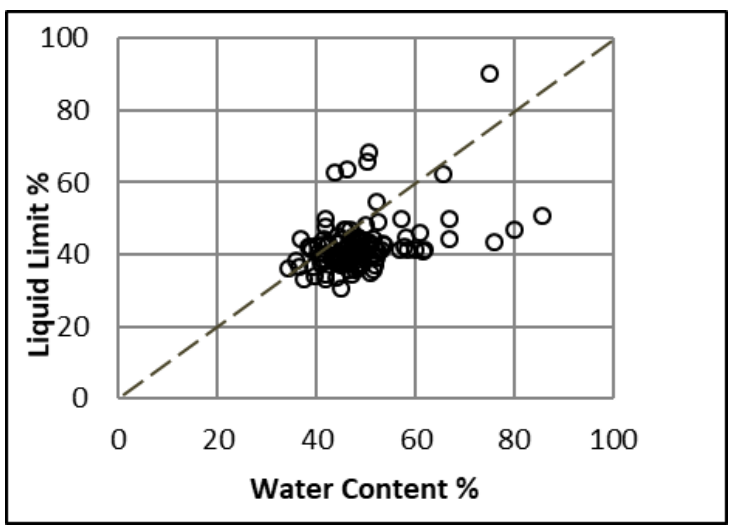

Fig. 2. Water content vs Liquid Limit

The natural water content is generally high with an average of $49 \%$, it is in most of the samples exceeding the Liquid limit as shown in Fig.2.

The average values of Atterberg limits and water content at each depth are plotted against sample depth in Fig.3, It can be seen that at all depths the water content is generally higher than the liquid limit.

Several consolidation tests on undisturbed samples taken from different depths were conducted using conventional Oedometer procedure in order to determine the over consolidation ratio by adopting the Casagrandi method, the results in Fig. 4 indicate that the soil is lightly over consolidated with OCR between 2-4 at shallow depths less than $2.5 \mathrm{~m}$, reduced to approximately 1.3 at larger depths.

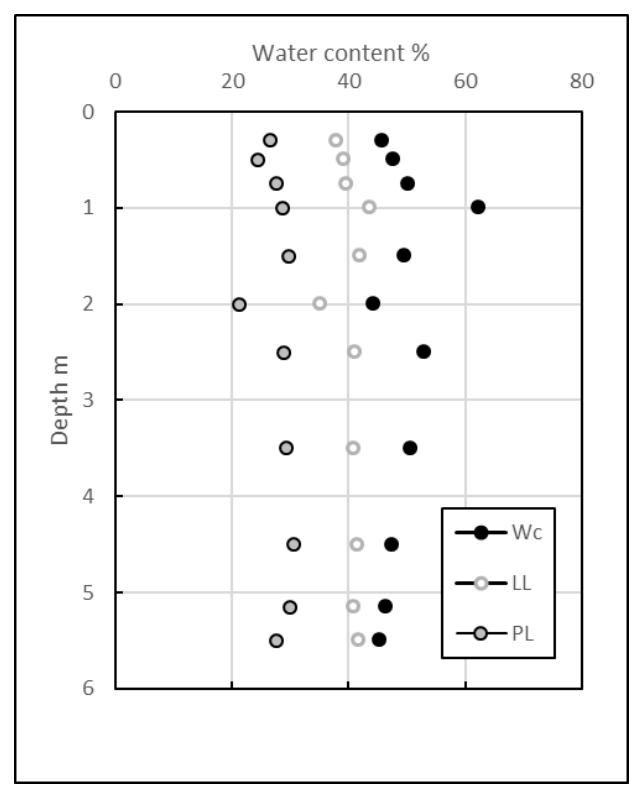

Fig. 3. Variation of water content and Atterberg limits with depth

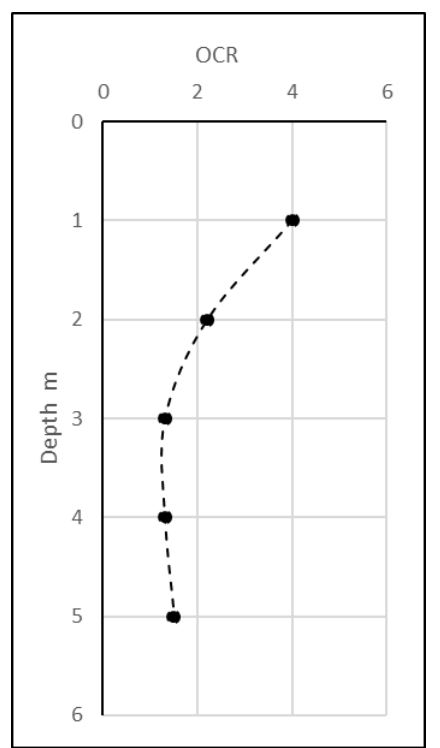

Fig. 4. Variation of OCR with depth

\section{Strength testing method}

\subsection{Triaxial Tests}

Directly upon placing the specimen inside the cell, it is immediately filled with water in order to allow some hydrostatic pressure to help maintaining specimen from becoming flabby. For samples recovered from shallow depths usually subjected to cell pressures higher than the corresponding value encountered in the field and generally not less than $50 \mathrm{kPa}$ in order to provide enough confinement and prevent specimen from buckling during shearing stage. Samples were tested in a strain controlled triaxial apparatus shown Fig. 5a at a constant rate of $0.60 \mathrm{~mm} / \mathrm{min}$ under unconsolidated undrained test condition. During testing the resulting force and displacement were recorded at small intervals in order to obtain smooth stress strain relationship. Because of initial soft condition of samples most samples were exhibiting high axial strain which led to noticeable sample bulging, and the majority of samples were not showing a clear failure plane (Fig. 5b). However, when deviator stress is maintaining constant value, the test usually terminated at nearly $15 \%$ strain.

\subsection{Miniature vane shear test}

The set up for a Miniature vane shear test, is shown in Fig. $5 \mathrm{c}$ and the testing procedure followed is according to ASTM D4648 [14]. The recorded strength is taken as the average of at least 3 measuring trials for each sample.

Measurement by the shear vane device was utilized for measuring both undisturbed and remolded shear strength. The undisturbed shear strength is measured by pushing the vane blades into the sample to at least twice its height and then rotate at a constant rotation speed and record the maximum equivalent torque. The remolded strength value is obtained by rewinding the vane back to its initial position before measuring undisturbed strength and rotate again for the second measurement, hence the new reading of maximum equivalent 


\section{Khatrush and El-Gehani, Vol.7, No.3, 2021}

torque is recorded. However, what is arbitrary called here a remolded shear strength measured this way is rather the mobilized residual shear along a pre-sheared surface since the sample original structure was not completely destroyed by remixing.

\section{Results and Discussions}

Attempts were made to test a total of (125) samples for the laboratory evaluation of undrained shear strength, only (59) samples were managed to be successfully tested in the UUtriaxial test and (84) in the (MV) apparatus. Table 2 contains a summary of the results of undrained shear strength obtained during testing of undisturbed samples in the triaxial apparatus and both undisturbed and remolded samples in the miniature vane shear device.

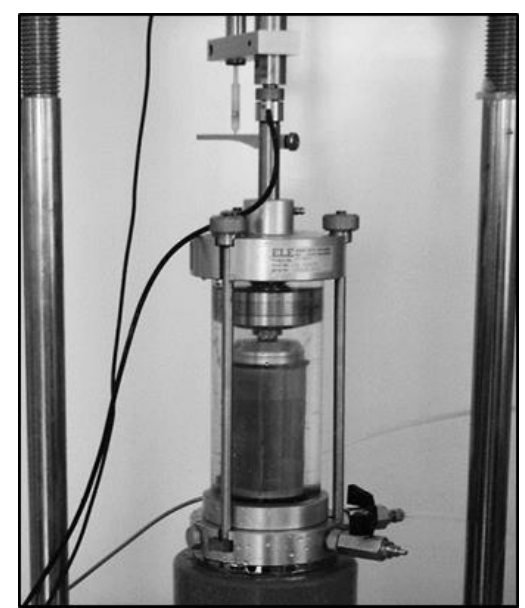

a) Triaxial test cell and sample.

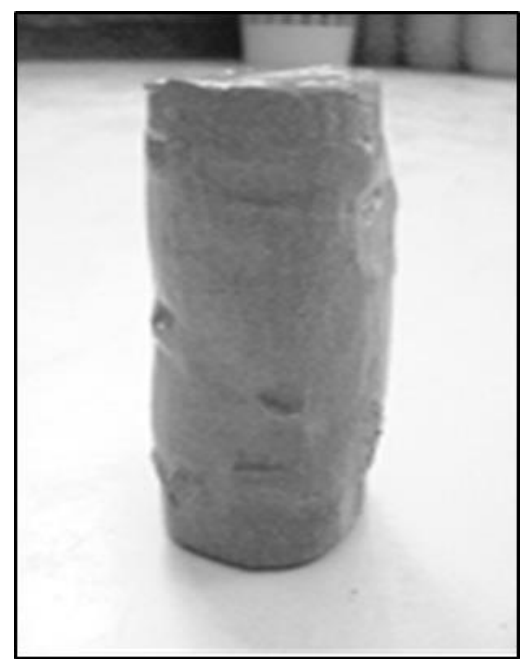

b) Typical sample after testing in Triaxial

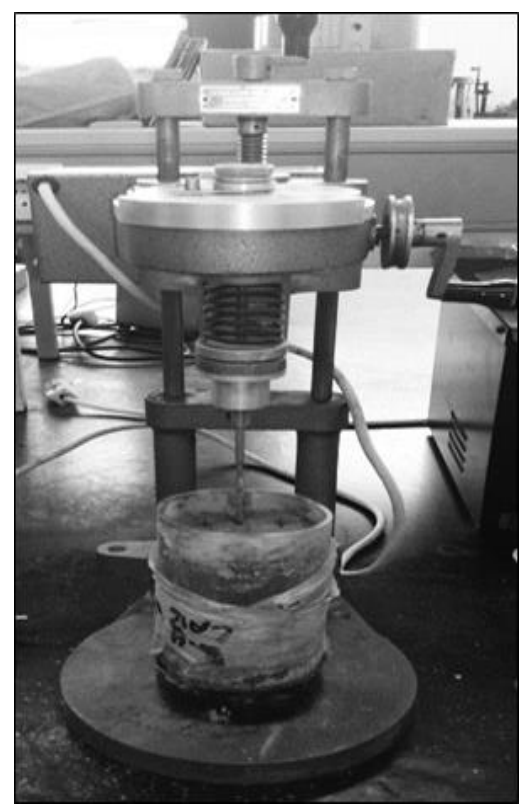

c) Vane shear test device and sample

Fig. 5. Testing samples and apparatus

Table 2. Summary of undrained shear strength results (kPa).

\begin{tabular}{|l|l|l|c|}
\hline Test & $\begin{array}{l}\text { Miniature } \\
\text { vane shear } \\
(\mathrm{MV}) \\
\text { undisturbed }\end{array}$ & $\begin{array}{l}\text { Miniature } \\
\text { vane shear } \\
(\mathrm{MV}) \\
\text { remolded }\end{array}$ & $\begin{array}{l}\text { UU- } \\
\text { triaxial }\end{array}$ \\
\hline Minimum & 6.9 & 3,9 & 5.0 \\
\hline Maximum & 39.1 & 24.1 & 28.0 \\
\hline Mean & 14.8 & 10.0 & 11.6 \\
\hline Standard Deviation. & 7.0 & 4.3 & 5.3 \\
\hline
\end{tabular}

\subsection{Undrained shear strength measured in triaxial test $(U U)$}

The resulting undrained shear strength $(\mathrm{Su})$ values obtained during triaxial testing are plotted against the vertical effective vertical pressure and presented in Fig. 6. The average undrained shear strength is $11.6 \mathrm{kPa}$ and of a maximum value is not exceeding $28 \mathrm{kPa}$. Despite, the scatter of the resulting $\mathrm{Su}$ which is seen at shallower depths less than $2.5 \mathrm{~m}$, with shear strength values above average, one can detect a slight tendency of increase of $\mathrm{Su}$ with depth especially at larger depths. Furthermore, Strength variability with depth may depend not only on the consolidation stresses (initially or mechanically induced), but also on the inherent variability of the soil layers [15]. Vipulanandan et al [16] analysed data collected from several places of soft marine soils around the world and suggested that, the trend of behaviour can be simulated by hyperbolic relationship between undrained shear strength $(\mathrm{Su})$ and in-situ vertical stress $(\sigma \mathrm{v})$ with an ultimate value of $\mathrm{Su}=$ $25 \mathrm{kPa}$ and a mean of $17.5 \mathrm{kPa}$. However, for the data in Fig.6 in which the resulting average of undrained shear strength obtained $(\mathrm{Su}=11.6 \mathrm{kPa})$, is only $66 \%$ of that mean value of soft soils. Bjerrum [1] evaluated methods to determine the undrained shear strength of soft clay soils and concluded that 


\section{Khatrush and El-Gehani, Vol.7, No.3, 2021}

the laboratory triaxial tests on undisturbed samples consolidated to in-situ effective stress better represented the strength of the soft soil, hence UU test is obviously underestimated the undrained shear strength. The soil with such low shear strength thus categorized accordingly as a very soft soil. It could simply be affected even by low level of vibration or any means of mechanical process such as handling and cutting. It could also easily deform during preparation and trimming prior to testing. However, for soft material the occurrence of some kind of disturbance is generally unavoidable and subsequently scatter in resulting $\mathrm{Su}$ is expected.

Furthermore, The scatter of $\mathrm{Su}$ at shallower depths shown in Fig. 6 may also be related to several factors such as the large variation of water content, changes in soil plasticity as previously illustrated in Fig. 3 and also the possible existence of random distribution of local material constituent or variation in density , However the higher average values of Su recorded at shallow depths is attributed to the condition of previous stress history experienced by the soil being lightly overconsolidated within these levels. However, to account for effect of overconsolidation ratio OCR, the results again plotted as $\mathrm{Su} / \mathrm{OCR}$ with the effective vertical stress and shown in Fig. 7, The relationship can be considered as linear with a slope of 0.28 which is slightly higher than that obtained by Misri [17] who suggested that the ratio between the undrained shear strength and pre-consolidation pressure is 0.22 .

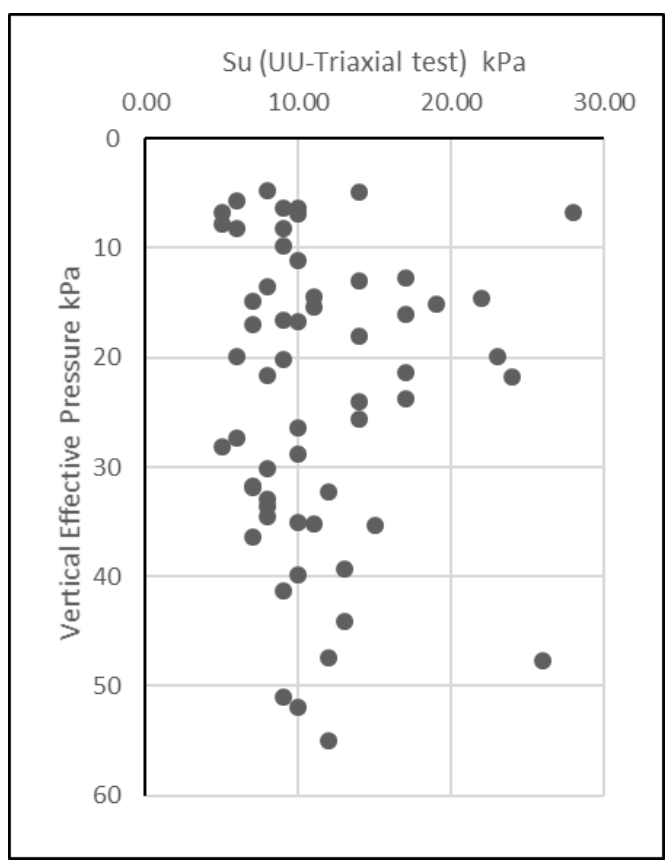

Fig. 6. Undrained shear strength vs vertical effective stress

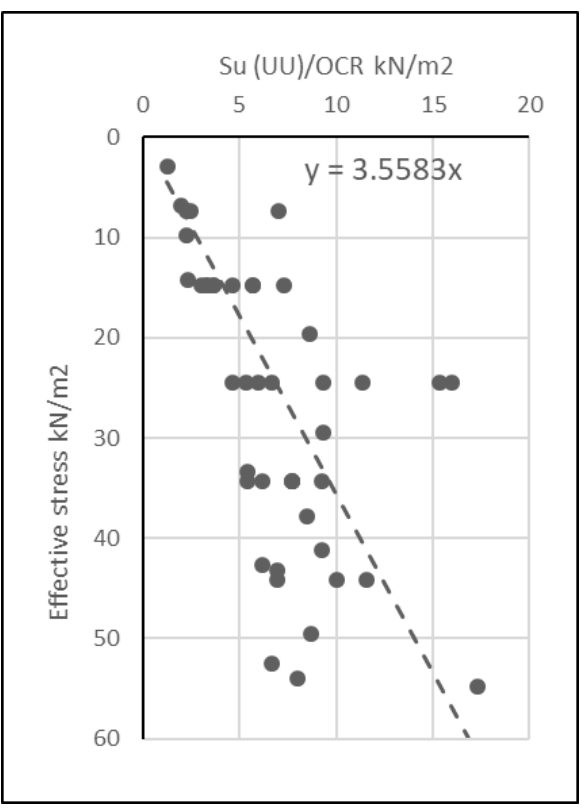

Fig. 7. Su (UU) vs vertical effective stress

\subsection{Undrained shear strength measured by miniature vane} shear test $(M V)$

\section{I- Undisturbed shear strength}

The results of undrained shear strength obtained using Miniature vane (MV) on undisturbed samples are plotted against sampling depth and shown in Fig. 8 together with UUtriaxial test results. The data in Table 2 indicated that the $\mathrm{Su}$ value evaluated by MV device is of an average of $14.8 \mathrm{kPa}$, it is generally $27 \%$ higher than that obtained during traixial test, the maximum recorded value of $\mathrm{Su}$ is $39.1 \mathrm{kPa}$. The variation with depth is not maintaining any regular pattern and highly scattered in case of both UU and MV test results. Some researchers $[12,18,11,10]$, related that to the effect of some sample disturbance.

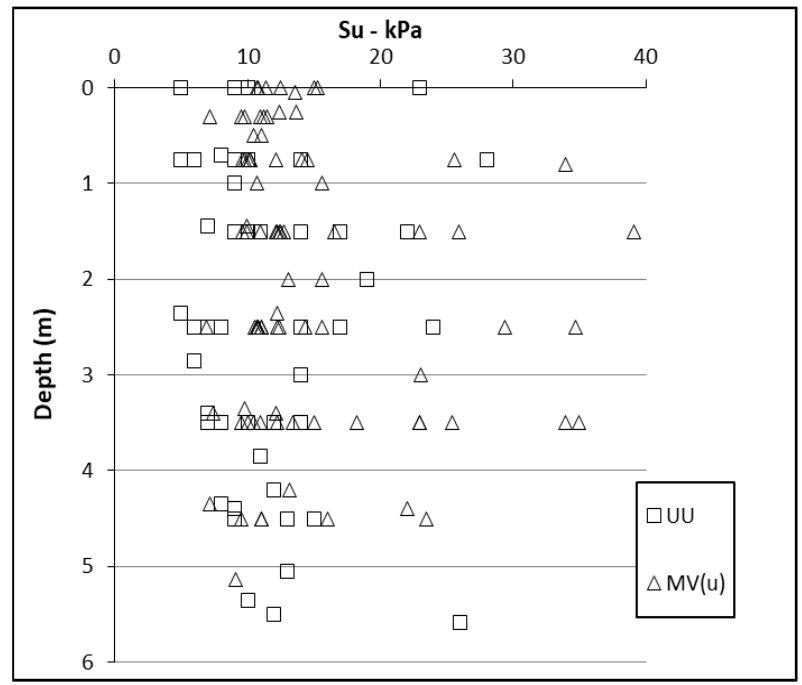

Fig. 8. Undrained shear strength vs depth measured by different devices 


\section{Khatrush and El-Gehani, Vol.7, No.3, 2021}

However, samples tested with MV device supposed to eventually exhibiting less disturbance, yet the large variability in the results was not reduced.

\section{II- Remolded shear strength}

The remolded shear strength measured by MV test device is with an average $\mathrm{Su}(\mathrm{r})$ of $10.0 \mathrm{kPa}$. The results are plotted against the undisturbed shear strength also obtained by MV device in Fig. 9. Good correlation can be seen from the results, the undisturbed strength is approximately 1.5 times the remolded value, nonetheless the soil is not showing high sensitivity upon remolding.

\subsection{Comparison of measured strength}

Referring to the results presented in Fig.8 the undrained strength $\mathrm{Su}$ measured by $\mathrm{MV}$ is generally higher than that obtained by Triaxial test (UU), As previously stated that the shear strength measured by MV were less affected by sample disturbance during testing. In fact, the variation in the measured undrained strength using deferent test methods is reported by several researchers $[19,20]$, the different testing procedure involving different total stress path or deferent mode of shearing for undrained strength measurement is consequently produce deferent values of Su. Fig.10 presents plots of shear strength evaluated by UU against that obtained by MV test results for undisturbed samples,

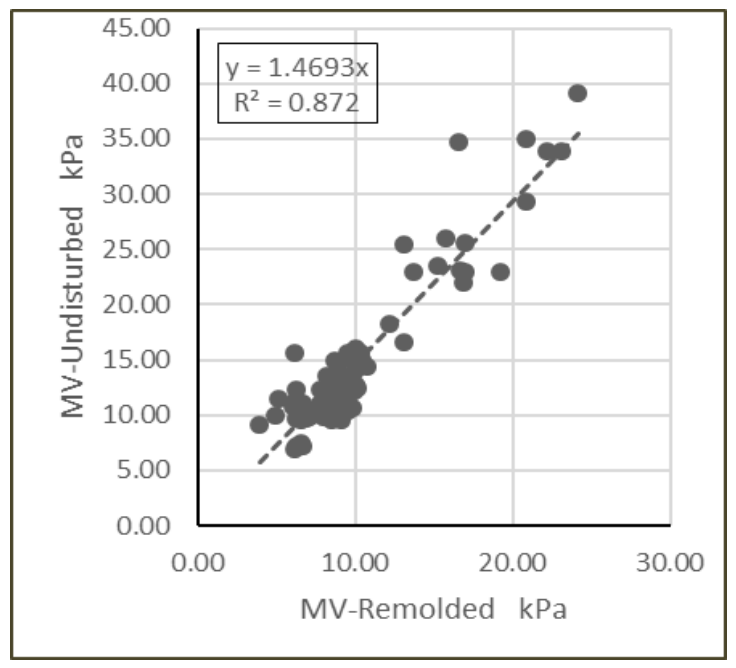

Fig. 9. Undisturbed strength vs remolded strength Using Miniature vane

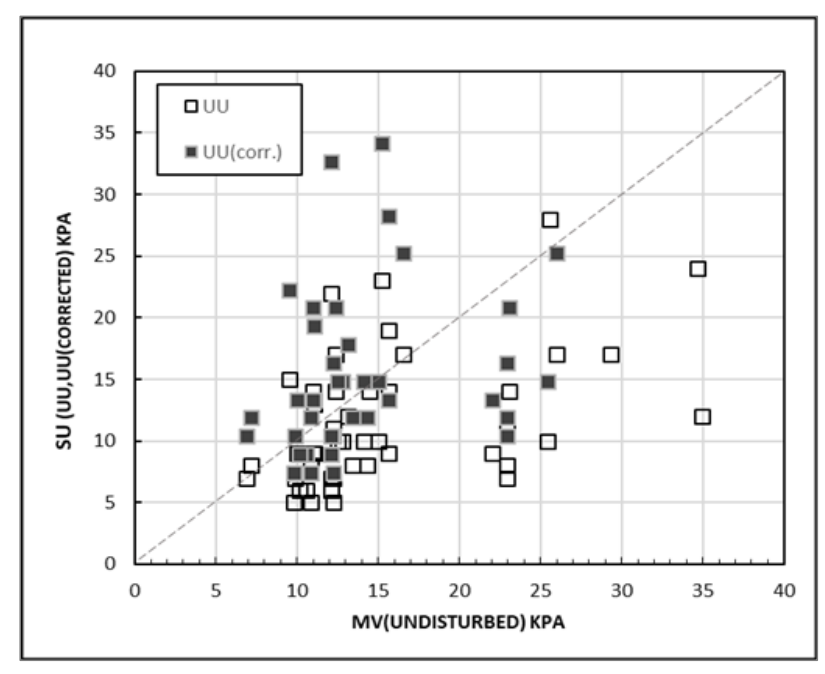

Fig. 10. Relation between results of Su from UU with Miniature vane

The shear strength values resulting from UU-triaxial test in Fig. 10 are generally lower than that obtained by MV device and as it was discussed earlier, the samples were very much affected by the process which preceded the testing and since during UU test, they have not been reconsolidated to their previous field effective pressure before testing. The reduction in measured $\mathrm{Su}$ in $\mathrm{UU}$ test compared with that measured by MV device is of the order of $27 \%$. The resulting low undrained shear strength obtained here by triaxial testing is mainly attributed to extra disturbance during pre-test preparation process.

Two sources of sample disturbance may exist in this case, the first is due to the process of field sampling and the second occurs during sample preparation in the laboratory, however soils of water content equals or above liquid limit should not be considered totally undisturbed and some change in its original state is inevitable [21]. The redistribution of water content within the sample before testing is commencing may also be considered a cause of strength reduction [1]. Furthermore, testing soft material in undrained condition without reconsolidation of the samples to the corresponding field effective stress before shearing is also responsible for the resulting shear strength reduction.

As it has been stated earlier the average undrained shear strength obtained from UU test during this study is only $66 \%$ of Su recommended by Vipulanandan et al [16] in his survey of undrained shear strength of soft marine soils around the world . Wroth [22] recommended the $\mathrm{Su}$ from isotropic consolidated undrained triaxial compression (CIUC) test as a standard test of reference for convenience in comparison of $\mathrm{Su}$ among various tests, Rataninikom et al [23] considered the resulting undrained shear strength from CIUC test as a reference to other test methods and hence, proposed some formulae to relate $\mathrm{Su}$ ) from different kind of testing method to that obtained during CIUC test, they express a relation with UU strength as given below; 
Khatrush and El-Gehani, Vol.7, No.3, 2021

$$
(\mathrm{Su})_{\mathrm{uu}}=0.673(\mathrm{Su})_{\mathrm{cicu}}
$$

Where; $(\mathrm{Su})_{\mathrm{uu}} \quad$ is the undrained shear strength obtained by UU-triaxial test

and $(\mathrm{Su})_{\text {cicu }}$ is the undrained shear strength obtained by isotopically consolidated undrained triaxial test.

However, If Eq. (1) is used for correcting the shear strength values obtained by UU-triaxial test during the present investigation, the resulting undrained strength (UU)-corrected becomes reasonably comparable with MV test results as shown in Fig. 10.

\section{4. $\quad$ Correlations with index properties}

Many researchers realize that both undisturbed and remolded undrained shear strength of cohesive soils is significantly affected by the change of water content and therefore, suggested several correlations of undrained shear strength either directly with the water content (Wc), $[24,4,9,16]$, plasticity index (PI) $[25,26]$; or liquidity index (LI), [21,27,28]. However, for the present work, since most of water content of tested samples are around liquid limit (LL) or above, with no wide range of $\mathrm{Wc}$, it was found more convenient to relate the undrained shear strength with Liquidity index. since it is expressed in terms of the water content above plastic limit (PL) with respect to plasticity index PI, hence positive value indicates Wc higher than LL. The test results of $\mathrm{Su}$ obtained from various tests are plotted against LI and presented in figures (11a to $11 \mathrm{~b}$ ), The results are highly scattered with broadly similar pattern, there is some kind of aggregation of low Su values mostly within a range LI between 0.5 and 1.5. However, this is generally the case for the results of every test type and whether the tested material being undisturbed or remolded, It is inevitable however to accept such discrepancy when testing natural material having high water content, the resulting trend is broadly emulated with other findings for soft soils in the sense that shear strength inversely proportional to liquidity index. The results, therefore are arbitrarily correlated, despite the high degree of discrepancy.

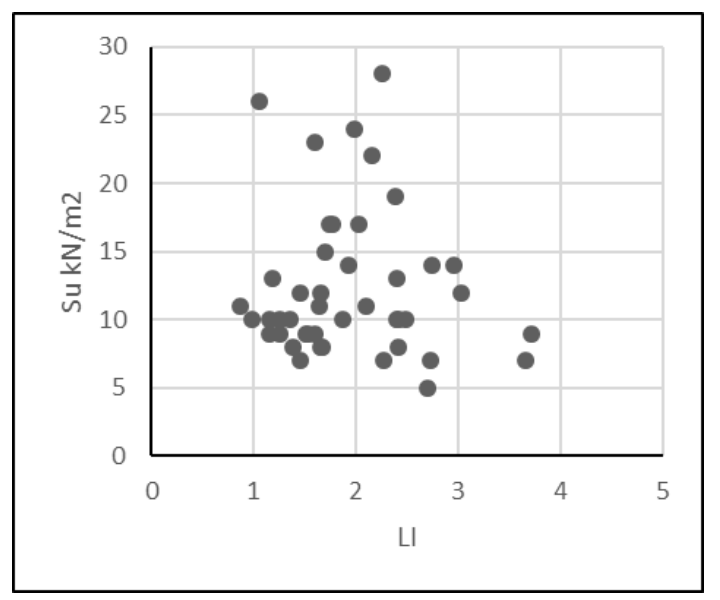

a) Relation of Su from UU-Triaxial and LI

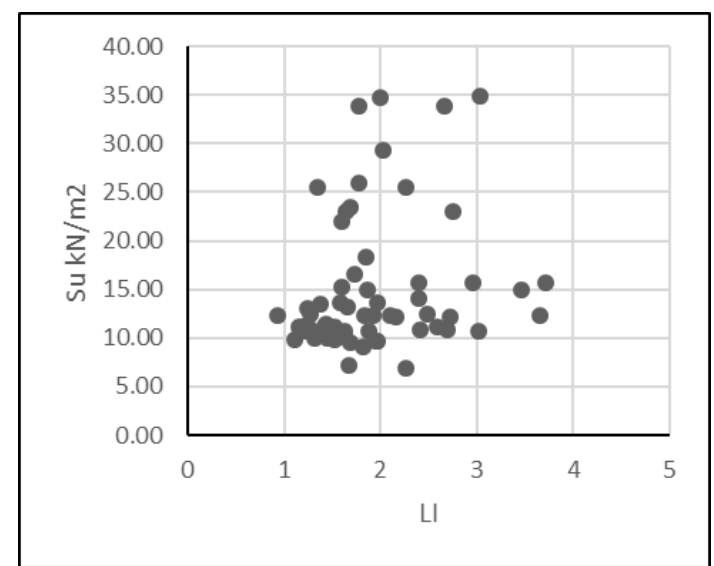

b) Relation of Su from Vane shear test (undisturbed) and LI

Fig. 11. Relation between results of $\mathrm{Su}$ from various tests with liquidity index

Bjerrum \& Simons [28] showed that, for normally consolidated sensitive clays, the undrained shear strength ratio from triaxial compression test (CIUC) can be correlated with the plasticity index (PI) and liquidity index (LI), However for soft soils with relatively high water content the correlation with LI is more convenient. Furthermore, the tested soil in this work is of very limited range PI. The equation proposed by Bjerrum and Simons [28] and also adopted by Rataninikom et al [23] is given below;

$$
\left(\mathrm{Su} / \sigma_{\mathrm{vo}}{ }^{\prime}\right)_{\mathrm{CIUC}}=0.18 / \mathrm{LI}^{0.5} \mathrm{OCR}^{\mathrm{m}}(\mathrm{LI} \text { in decimal })
$$

Where $\left(\mathrm{Su} / \sigma_{\mathrm{vo}}{ }^{\prime}\right)$ is the normalized undrained strength ratio and $\sigma_{\mathrm{vo}}$ ' is the effective overburden pressure. OCR is taken as 1.3 for normally consolidated soil and $\mathrm{m}=0.8$.

Some researchers suggested that the relation is better expressed in terms of the normalized undrained strength $\mathrm{Su} /$ бp $^{\prime}$ [17], and emphasized on the consideration of $\sigma_{\mathrm{p}}{ }^{\text {' on developing }}$ a correlation of $\mathrm{Su}$ with index soil properties for low overconsolidation clay [29]. However, since the samples taken from shallow depths are lightly over consolidated, the test results can be better normalized with the average pre-consolidation $\sigma_{\mathrm{p}}$ ' considering average $\mathrm{OCR}=2.0$ and $\mathrm{m}=0.8$, therefore, Eq. (2) can slightly be modified so that;

$$
\left(\mathrm{Su} / \sigma_{\mathrm{p}}{ }^{\prime}\right)_{\mathrm{CIUC}}=0.45 / \mathrm{LI}^{0.75} \mathrm{OCR}^{\mathrm{m}}
$$

The results are plotted in Fig. 12, the scatter still high but it demonstrates better correlation of the data with Eq. (3) after considering the soil as lightly over-consolidated with average $\mathrm{OCR}=2.0$. 


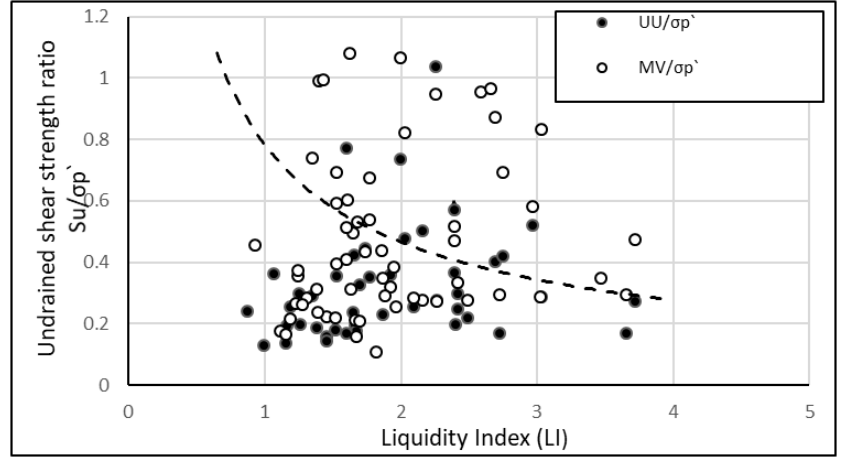

Fig. 12. (Su/øp') vs Liquidity Index

\section{Conclusion}

A series of laboratory tests were carried out on soft marine deposit utilizing two methods of testing UU-triaxial and Miniature vane shear (MV) tests. The following are the main conclusions;

Testing soft soils of high water content equals to liquid limit or higher is generally a difficult matter, therefore the use of unconsolidated undrained triaxial test to determine the undrained shear strength is only possible by providing extra care during sample preparation and testing stages. It is admitted that certain degree of sample disturbance could not be avoided.

The adopting of a simple strength index device such as Miniature vane to evaluate the undrained shear strength and reducing sample disturbance is considered an effective method and a reasonable alternative. In the present work the shear vane device was able to predict the undrained shear strength of about $27 \%$ higher than that obtained by UU-triaxial.

Attempt to relate the undrained shear strength with Liquidity index LI was only arbitrarily made possible despite of high scatter of the data it is generally comparable just with the trend reported by other research workers. The relation between undrained shear strength ratio $\left(\mathrm{Su} / \sigma_{\mathrm{p}}{ }^{\prime}\right)$ and $\mathrm{LI}$ was found better represented by the equation suggested by Bjerrum and Simons (1960) with some modification and consideration of the effect of over-consolidation ratio.

\section{Acknowledgements}

The authors wish to thank the Libyan Technical Consultancy (LTC) for their support and making the laboratory test data available.

\section{References}

[1] Bjerrum L (1973) Problems of soil mechanics and construction on soft clays. Proceedings 8th Int. Conf. Soil Mech. and Found. Eng. Moscow, 3: 111-159

[2] Lunne T, Berre T, Strandvik S (1997) Sample disturbance effects in soft low plastic Norwegian clay. Conference on Recent Developments in Soil and Pavement Mechanics, Rio de Janeiro, June 1997, 81-102

[3] Nearing, M.A and West L.T (1988) Soil strength indices as indicators of consolidation, American society of agricultural engineers, vol. 31(2)
[4] Leoni A.J (2009) Characterization of post pampean clays, Proceedings of the 17th International Conference on Soil Mechanics and Geotechnical Engineering Alexandria

[5] Vahedifard F, Isaac L. Howard, Walaa H. Badran M., William D. Carruth C., (2016) Strength indices of highmoisture soils using handheld gauges, Proceedings of the Institution of Civil Engineers - Ground Improvement vol 169, No.3

[6] Howard, I. \& Badran, W. (2011) Comparison of Hand Held Gage and Unconfined Compression Results in Low Strength Cementitious Stabilized Materials. Geo-Frontiers 2011: pp. 2574-2583.

[7] Kayabali K. (2011), Consistency limits - A reappraisal, EJGE, vol. 16

[8] Mohd J., Mohd A., Taha, R. Ahmed J Abu Kassim A. Jamaludin A, J. \& Jaaadil A (1997) Prediction and Determination of Undrained Shear Strength of Soft Clay at Bukit Raja, Pertanika J.Sci. \& Technology, (5), pp111-126.

[9] Ghosh R. (2013), Effect of soil moisture in the analysis of undrained shear strength of compacted clayey soil, J. civil Eng. \& construction technology, vol. 4(1), pp 23-31

[10] Velosa, C.L. Remmes, B., and Bik, M. (2013). Strength characterization of soft marine deposits off East Africa using the CPT Stinger method. Report by TDI-Brooks International, Inc., 14391 S. Dowling RD, College Station, TX 77845, USA.

[11] Li Y., Hu G., Wu N., Liu C., Chen Q., Li C., (2019) Undrained shear strength evaluation for hydrate-bearing sediment overlying strata in the Shenhu area, northern South China Sea, Acta Oceanologica Sinica -English Edition38(3):114-123

[12] Ebrahimian B., Movahed V., Nazari A. (2013) Soil charactrisation of South pars field persian gulf, Envirnmental geotechnics Volume 1 Issue 2, May 2014, pp. 96-107.

[13] ASTM D3213-91(1997) Standard Practices for Handling, Storing, and Preparing Soft Undisturbed Marine Soil STANDARD by ASTM International.

[14] ASTM D4648 -00 (2016) Standard Test Methods for Laboratory Miniature Vane Shear Test for Saturated FineGrained Clayey Soil. STANDARD by ASTM International

[15] D'Ignazio M. and Phoon K. (2016), Correlations for undrained shear strength of Finnish soft clays, Canadian Geotechnical Journal, 53(10)

[16] Vipulanandan C., Ahossin Guezo Y.J. and Bilgin O. (2007) Geotechnical Properties of Marine and Deltaic Soft Clays, Advances in Measurement and Modelling of Soil Behaviour, Geo-Denver: New Peaks in Geotechnics

[17] Mesri, G. (1989). A re-evaluation of $\mathrm{su}(\mathrm{mob})=0.22 \sigma p$ ' using laboratory shear tests. Canadian Geotechnical Journal, 26(1): 162-164.

[18] Barros J. M. C. Amaral C. S \& Silveira R. M. S (2009) Geotechnical properties of Brazilian marine clays Proceedings of the 17th International Conference on Soil Mechanics and Geotechnical Engineering Alexandria 
[19] Mayne p w Coop M R Springman S Huang A B and Zoenberg J 2009, Geomaterial behaviour and testing, 17th ICSMGE EGYPT Vol 4 pp 2777-2872

[20] Kamei K. (1996) Undrained shear strength and interrelationships among CIUC, CKoUC, CIUE, and CKoUE tests, Geoscience RepL, Shimane Univ., 15, p. I 37-145

[21] O`Kelly B.C. (2013) Atterberg limits and remoulded shear strength - water content relationships ASTM Geotechnical testing journal, vol.36, No 6

[22] Wroth C.P. (1984), The interpretation of in situ soil tests, Geotechnique 34, No. 4,

[23] Ratananikom W., Yimsiri S., and Likitlersuang S., (2015), Undrained Shear Strength of Very Soft to Medium Stiff Bangkok Clay from Various Laboratory Tests, Geotechnical Engineering, Journal of the SEAGS \& AGSSEA Vol. 46 No.1

[24] Sharma \& Bora B.K. (2003) Plastic Limit, Liquid Limit and Undrained Shear Strength of Soil-Reappraisal ASCE J geotechnical and geoenviromental engineering.
[25] Skempton, A.W. (1957) "The Planning and Design of New Hong kong Airport". Proceeding. London: Institute of Civil Engineering, 7 305-307.

[26] Lemos S.G.F.P. and Pires P.J.M. (2017), The Undrained Strength of Soft Clays Determined from Unconventional and Conventional Tests, Soils and Rocks, São Paulo, 40(3): 291 301.

[27] Koumoto, T. \& Houlsby, G. T. (2001). Theory and practice of the fall cone test, Geootechnique 51, No. 8,

[28] Bjerrum, L., \& N.E. Simons. (1960) Comparison of Shear Strength Characteristics of Normally Consolidated Clay. Proceedings. Research Conference on Shear Strength of Cohesive Soils, 1771-1726.

[29] DeGroot D.J., Lunne T., Shankar R., Knudsen S., Jones C.D. and Yetginer-Tjelta T. I. (2016) Engineering properties of low to medium overconsolidation ratio offshore clays, AIMS Geosciences, 5(3): 535-567. 